
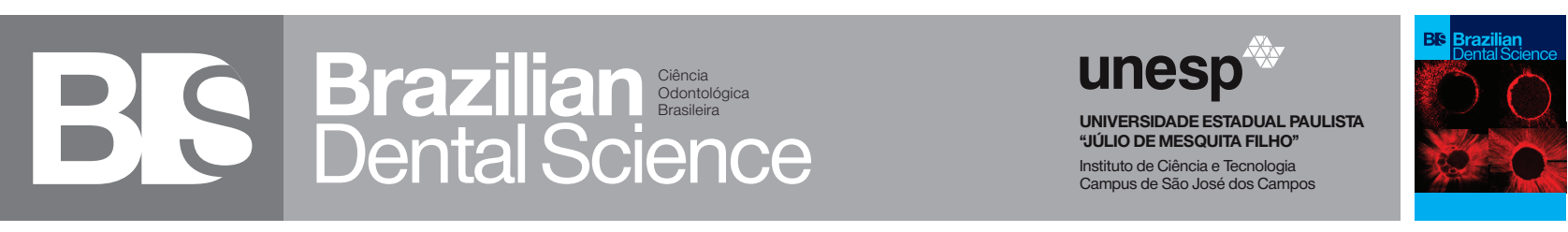

\title{
Effect of erosive challenge and cigarette smoke on dentin microhardness, surface morphology and bond strength
}

Efeito de desafios erosivos e fumaça de cigarro na microdureza, morfologia de superfície e resistência de união à dentina

\author{
Marcela Alvarez FERRETTI ${ }^{1}$, Jéssica Dias THEOBALDO ${ }^{1}$, Renata PEREIRA ${ }^{1}$, Waldemir Francisco VIEIRA-JUNIOR ${ }^{2}$, Gláucia Maria Bovi \\ AMBROSANO $^{3}$, Débora Alves Nunes Leite LIMA ${ }^{1}$, Flávio Henrique Baggio AGUIAR ${ }^{1}$ \\ 1 - Department of Restorative Dentistry - Piracicaba Dental School - University of Campinas - Piracicaba - SP - Brazil. \\ 2 - São Leopoldo Mandic Institute and Dental Research Center Campinas - Campinas - SP - Brazil. \\ 3 - Department of Bioscience - Piracicaba Dental School - University of Campinas - Piracicaba - SP - Brazil.
}

\begin{abstract}
Objective: This study aimed to evaluate the surface microhardness and morphology, as well as the microshear bond strength of a self-etching adhesive (Clearfil SE, Kuraray) to eroded dentin, exposed or not to cigarette smoke. Forty dental crowns were divided into 4 groups $(n=10)$ : no treatment (control) $(C)$; erosion (E); erosion + cigarette smoke exposure (ES); cigarette smoke exposure (S). Samples were prepared through third molars polishing until dentin exposure, followed by crown section. Erosive cycles were performed 5 times/day for $30 \mathrm{~s}$ at $60 \mathrm{~min}$ intervals. Cigarette smoke was produced with twenty cigarettes/day, during 5 days. Microhardness was evaluated initially and after the treatments. Microshear bond strength was tested after the treatments and dentin restoration with flow composite. Failure patterns and dentin morphology was evaluated by Scanning Electron Microscopy. Microshear bond strength data was submitted to two-way ANOVA, microharness test was adjusted by gamma distribution to be a non-parametric analyses $(\mathrm{p}=0.05)$, and surface morphology as qualitative analyses. Loss percentage of microhardness was observed only in groups submitted to erosion. Bond strength was statistically similar between all groups. The most prevalent failure pattern was of adhesive type. Morphological analysis of dentin showed obliterated tubules in groups submitted to cigarette smoke exposure. Cigarette smoke exposure did not promote any effect in the percentage of microhardness loss, as in sound dentin as in eroded dentin. Cigarette smoke, erosion, and association of both, did not alter the bond strength of self-etching adhesives to dentin.
\end{abstract}

\section{KEYWORDS}

Bond strength; Cigarette Smoke; Dental erosion; Microhardness; Self-etching adhesives.

\section{RESUMO}

Objetivo: Este estudo teve como objetivo avaliar a microdureza (\% perda de dureza) e morfologia de superfície (MS), assim como a resistência de união (RU) de um adesivo autocondicionante (Clearfil SE, Kuraray) à uma dentina erodida, exposta ou não à fumaça de cigarro. Material e Métodos: Quarenta coroas dentais de terceiros molares foram seccionadas da raiz e polidas até a exposição dentinária, sendo aleatoriamente divididas em 4 grupos $(n=10)$ : sem tratamento (controle), erosão (E), erosão+ exposição a fumaça de cigarro (ES); exposição a fumaça de cigarro (S).O ciclo erosivo foi realizado 5 vezes/ dia por 30s, com 60 minutos de intervalo entre eles. Os grupos ES e $\mathrm{S}$ foram exposto à fumaça de cigarro produzida por 20 cigarros/dia, durante 5 dias. A avaliação da microdureza foi realizada antes e após os tratamentos, enquanto a resistência da união por microcisalhamento foi realizada após os tratamentos Os padrões de fratura representativos e a MS dentinária foram avaliados por microscopia eletrônica de varredura (MEV). Os dados de RU foram analisados por ANOVA dois fatores, enquanto a análise de microdureza foi ajustada por distribuição gama por ser uma análise não-paramétrica $(\mathrm{p}=0.05)$. A MS foi analisada qualitativamente. Resultados: Os grupos expostos aos ciclos erosivos (E e ES) apresentaram \% de perda de dureza significativamente menor que os grupos não expostos (Controle e S. aos ciclos erosivos (E e ES). Para RU, não houve diferença estatística significativa entre os grupos. O padrão de fratura mais observado foi do tipo adesivo, e através das imagens obtidas por MEV, observouse a obliteração de túbulos dentinários no grupo exposto à fumaça de cigarro, enquanto os grupos submetidos aos ciclos erosivos (E e ES) apresentaram maior exposição e diâmetro de túbulos dentinários. Conclusão: A exposição à fumaça de cigarro não promove nenhum efeito quanto a perda de porcentagem de dureza dentinária, assim como em dentina erodida e saudável. A fumaça de cigarro, o processo erosivo, e a associação de ambos, não altera a resistência da união de adesivos autocondicionantes à dentina.

\section{PALAVRAS-CHAVE}

Força de união; Fumaça de cigarro; Erosão dentária; Microdureza; Adesivos autocondicionantes; 


\section{INTRODUCTION}

$\mathrm{D}$ ata published by World Health Organization (WHO) indicated that around two billion people use tobacco worldwide [1], being considered a public health problem, since its associated with more than 7 million deaths per year [2]. Smoking is considered a complex and highly dynamic process, which has as its product fuel, a hazardous smoke by a gaseous phase and a particulate one, with more than 3,800 compounds, negatively influencing the general and oral health of the individual $[3,4]$. In the oral cavity, changes in color, surface roughness and microhardness of both the dental structure and restorative materials may occur, and the bond strength of some dentin bonding systems may be reduced, and these substances are important for the clinical success of restorations [5-8].

Furthermore, smoke habit it is frequently associated with the acid beverages consumption, which have a highly erosive potential (for example-based coca soft drinks and coffee) thus increasing the susceptibility of dental erosion [9-12]. According to Ten Cate and Imfeld (1996), tooth erosion is defined by loss of tooth mineral structure through acids agents, without involvement of bacteria, which is a pathological process classified as acute or chronic [13]. Depending on the severity of exposure, there is the possibility of dentin exposure, therefore dentin hypersensitivity, in addition to reduced chewing capacity $[9,14]$. Once the dentin tissue exposure, there is a necessity for restorative treatments to replace lost tissue $[15,16]$.

Restorative success is closely associated with an effective bonding procedure between adhesive system and dental tissue. Although the development of adhesives is growing, bringing significantly improvements to adhesive area, substrate- adhesive interface, denominated hybrid layer, it is still been the most susceptible area to degradation in buccal medium [17]. Literature shows several factors that interfere with bond success, such as blood contamination, saliva, erosion [18] and cigarette smoke exposure $[7,8]$. Some studies suggest that cigarette smoke modified the dental structure due to collagen matrix degradation, organic part, and changes in hydroxyapatite crystals through heavy metal's deposition [5,19]. According to Almeida \& Silva et al. (2010) and Theobaldo et al. (2016), these heavy metal contaminations can be associated with the decrease of bond strength of some adhesive systems, in order to the changes in the dentin substrate $[7,8]$. Owing to this, the aim of this study was evaluated the causing effects of cigarettes smoke in an eroded dentin, regarding interference of bond strength of self-etching adhesive systems and superficial microhardness.

The null hypothesis of this study is that dentin exposure to erosive cycles associated with exposure to cigarette smoke would not influence on surface microhardness and bond strength of self-etching adhesives.

\section{MATERIAL AND METHODS}

Forty freshly extracted human third molars were selected with approval by the Ethics Committee in Research of Piracicaba Dental School, University of Campinas (register number 57972916), and were kept in 0.9\% saline solution for up to two months. Teeth's debris was removed with scalpel blade and surfaces were cleaned with pumice powder (SS White LTDS, Rio de Janeiro, $\mathrm{RJ}$, Brazil) and water.

After cleaning, the enamel was abraded in a polishing machine (Politriz, AROTEC; São Paulo, SP, Brazil) with 100-grit silicon carbide abrasive paper (Norton Abrasivos; Vinhedo, SP, Brazil) until obtainment of a flat dentin occlusal surface. The dentin surface was then polished sequentially with 600- and 1200-grit silicon carbide abrasive papers in the same machine, under constant water-cooling, to obtain a flat surface. For the last grit, each specimen was polished for $30 \mathrm{~s}$ in order to standardize the smear layer. Teeth were sonicated (Ultrasound Ultrason 1440 D-Odontobrás; Rio Preto, SP, Brazil) for $15 \mathrm{~min}$ after each abrasive paper in order to remove polishing debris, until grit 600 .

At the end of dentin polishing, the teeth were affixed to a metallographic precision cutter (Isomet 1000, Buehler; Lake Bluff, IL, USA), in which a diamond blade (Isomet Diamond Wafering Blades, Buehler, IL, USA) sectioned the roots from the crowns, under water-cooling at $250 \mathrm{rpm}$. The roots were discarded and the crowns were used as samples for the tests perform. 
The samples were allocated in 4 groups, according to their treatment: no treatment (control) (C); just erosion (E); erosion + cigarette smoke exposure (ES); just cigarette smoke exposure (S).

\section{Erosion simulation}

Samples from $\mathrm{s}$ and third groups were immersed in $0.3 \%$ citric acid solution $(\mathrm{pH} \sim 3.25)$ for $30 \mathrm{~s}$ while stirring (173 rpm), followed by 60 minutes in artificial saliva solution ( $\mathrm{pH} 7)$. The procedure was repeated five times and samples were stored in artificial saliva [20].

\section{Cigarette smoke exposure}

Samples from third and fourth groups were submitted to cigarette smoke exposure. For this purpose, a smoke machine developed by the Department of Restorative Dentistry of Piracicaba Dental School (registered under Number 01810012043 INPI - National Institute of Industrial Property) was used. The machine allows the impregnation of cigarettes compounds, such as pigments, into dental structures and restorative materials, in order to reproduce the conditions of smokers' oral cavity. The machine works by aspirating and conducting cigarette smoke through compartments, so that smoke circulates in the environment, allowing the deposition of chemicals over the samples. The cycle is programmed within a time interval of $3 \mathrm{~s}$, which simulates smoke aspiration normally performed by a smoker. A timer allows ambient air to be inhaled every $10 \mathrm{~s}$, thus simulating smoke exhaustion and subsequent elimination.

The samples were submitted to smoke exposure from a pack of Marlboro cigarette (Philip Morris Brazil Ind. Com. Ltda., Santa Cruz do Sul, RS, Brazil), namely 20 cigarettes per day, over a 5-day period [21]. During the whole procedure, the samples were stored in artificial saliva at $37^{\circ} \mathrm{C}$. Every $24 \mathrm{~h}$, the samples were washed with distilled water and re-immersed in new artificial saliva solution, in order to prevent sedimentation of cigarette smoke compounds [21].

\section{Microhardness test}

Surface microhardness test was performed before and after the treatments. For this purpose, the samples were fixed to acrylic discs with sticky wax, so that dentin surfaces remained parallel to the acrylic base. Knoop microhardness value (KHN) was obtained through arithmetic mean of five indentations, considering $5 \mathrm{~g}$ load for $5 \mathrm{~s}$ and $100 \mu \mathrm{m}$ apart.

After initial and final tests, the percentage of microhardness loss was calculated through the formula: $\%$ microhardness loss $=$ (KHNinitial KHNfinal) * 100 / KHNinitial.

\section{Microshear bond strength test}

A self-etching 2-step adhesive system (Clearfil SE, Kuraray, Tokyo, Japan) was applied to dental structures after surface microhardness analysis, according to manufacturer's instructions: active application of primer for $20 \mathrm{~s}$, gentle air drying, bond application, gentle air drying, and light activation for $10 \mathrm{~s}$. Subsequently, the dentin surfaces received a composite resin restoration (Filtek Z350 XT Flow, 3M Oral Care, St. Paul, MN, USA), confectioned with a perforated bucatini pasta matrix (Furadinho 6, Pastifício Santa Amália, Machado, MG, Brazil), presenting $1 \mathrm{~mm}$ high and $1.04 \mathrm{~mm}$ internal diameter. Light activation of the specimens was performed for $20 \mathrm{~s}$ with light emitting diode device (Valo, Ultradent Products, South Jordan, UT, USA), in High Power mode - $1400 \mathrm{~mW} / \mathrm{cm}^{2}$.

The specimens were attached to a device with cyanoacrylate-based glue (Super Bond gel, Loctite, Henkel, São Paulo, SP, Brazil) by their extremities. Then, the set was fitted on a Universal Testing Machine (EZ Test L, Shimadzu, Kyoto, Japan) and the microshear bond strength test was conducted with $\pm 5 \mathrm{~N}$ load cell at a crosshead speed of $0.5 \mathrm{~mm} / \mathrm{min}$ until failure. The crosssectional area at the side of fracture was measured with a digital caliper (Mitutoyo Corporation, Tokyo, Japan), and microshear bond strengths were reported in MegaPascal (MPa).

\section{evaluation \\ Failure patterns and dentin morphology}

After treatments and tests performing, the samples were sputter-coated with gold in a vacuum evaporator (SCD 050, Bal-Tec AG, Balzers, Liechtenstein). A scanning electron microscope (JSM 5600 LV, JEOL, Tokyo, Japan) was used to evaluate dentin morphology, i.e. surface changes, and fracture patterns, which were classified as: (1) cohesive in dentin, (2) adhesive, (3) cohesive in composite and (4) mixed, considering as cohesive 
and adhesive fractures when at least $70 \%$ of the total area was composed by the same pattern. Mixed fracture was stated when there was more than one pattern and none prevailed.

\section{Statistical analysis}

Data's normality and equality of the variances were observed. Bond strength variable met the assumptions of parametric analysis. Microhardness variable did not meet the assumptions of parametric analysis. Thus, bond strength variable was analyzed by two-way ANOVA and microhardness variable presented asymmetric distribution. A generalized linear model was adjusted considering gamma distribution (asymmetric shape). In all analyzes, a significance level of $5 \%$ was considered.

\section{RESULTS}

Table I shows the values for the percentage of surface hardness loss after the treatments. It was possible to observe a statistically significant difference only for the groups whose specimens were submitted to the erosive process ( $\mathrm{E}$ and ES) when compared to the groups not submitted to erosion. (C and S) ( $p=0.0145)$. There was not statistically significant difference for smoke factor $(p=0.8790)$ and for the interaction between factors $(\mathrm{p}=0.5296)$.

Table I - Mean (Standard deviation) for the percentage of microhardness loss in dentin substrate.

\begin{tabular}{|ccc|}
\hline & Without Erosion & Erosion \\
\hline Without Cigarette Smoke & $11.28(14.17) \mathrm{Ba}$ & $30.20(9.85) \mathrm{Aa}$ \\
\hline Cigarette smoke & $17.60(11.51) \mathrm{Ba}$ & $27.27(9.96) \mathrm{Aa}$ \\
\hline
\end{tabular}

Means followed by same letters did not differ each other. Horizontal uppercase letter and vertical lowercase letter.

Table II shows the values for bond strength to dentin substrate. No statistically significant differences were observed for both factors: cigarette smoke exposure $(\mathrm{p}=0.4492)$ and erosion $(\mathrm{p}=0.7221)$, and the interactions between factors $(\mathrm{p}=0.5401)$.

Table II - Mean (standard deviation) of dentin bond strength in $\mathrm{MPa}$.

\begin{tabular}{ccc} 
& Without Erosion & Erosion \\
\hline Without Cigarette Smoke & $9.9(4.3) \mathrm{Aa}$ & $11.6(5.3) \mathrm{Aa}$ \\
Cigarette smoke & $12.3(8.0) \mathrm{Aa}$ & $11.8(3.6) \mathrm{Aa}$ \\
\hline
\end{tabular}

Means followed by same letters did not differ each other. Horizontal uppercase letter and vertical lowercase letter.
For fracture pattern, data were distributive in graphic in accordance with the frequency of the fractures (Figure 1). The predominantly pattern found in all groups was adhesive failure, except for the group that was exposed only to cigarette smoke (F). For group F, the predominantly pattern was mixed failure.

Images obtained by SEM, Figure 2 (A), correspond to control group without erosion (C). It is possible observed the presence of dentin tubules exposed irregularly and integrate mineral surface. Figure 2 (B) were represented dentin surfaces of control group exposed to erosive cycle (E). In the images, tubules are exposed in several quantities and with a bigger diameter in comparison with to control group (C) and exposed only to cigarette smoke (S), both without erosive challenge. It is observed the demineralization caused by irregular intertubular areas. Figure 2 (C) corresponds to group ES, which has the dentin surface exposed both to cigarette smoke and erosive cycle. It is observed the same superficial alterations found in the group $\mathrm{E}$, however the tubules are obliterated, which suggest a material deposition from cigarette smoke. Groups exposed only by cigarette smoke (S) showed 2 types of surface pattern (Figure 2D and D1). In Figure 2 (D) observed a significantly decrease in the quantity of exposed dentin tubules, due to their obliteration (magnification 4000x) occurred by cigarette smoke deposition. The same pattern is observed in figure 2 (D1).

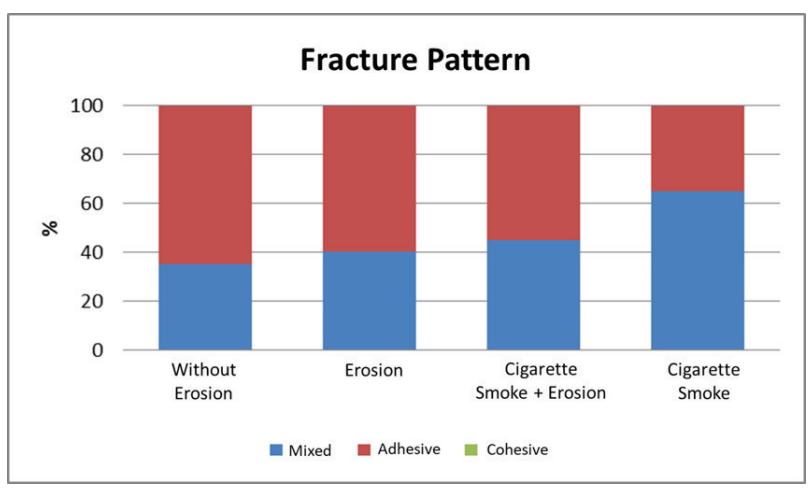

Figure 1 - Percentage of fracture pattern. The failures were classified as mixed, adhesive and cohesive. 

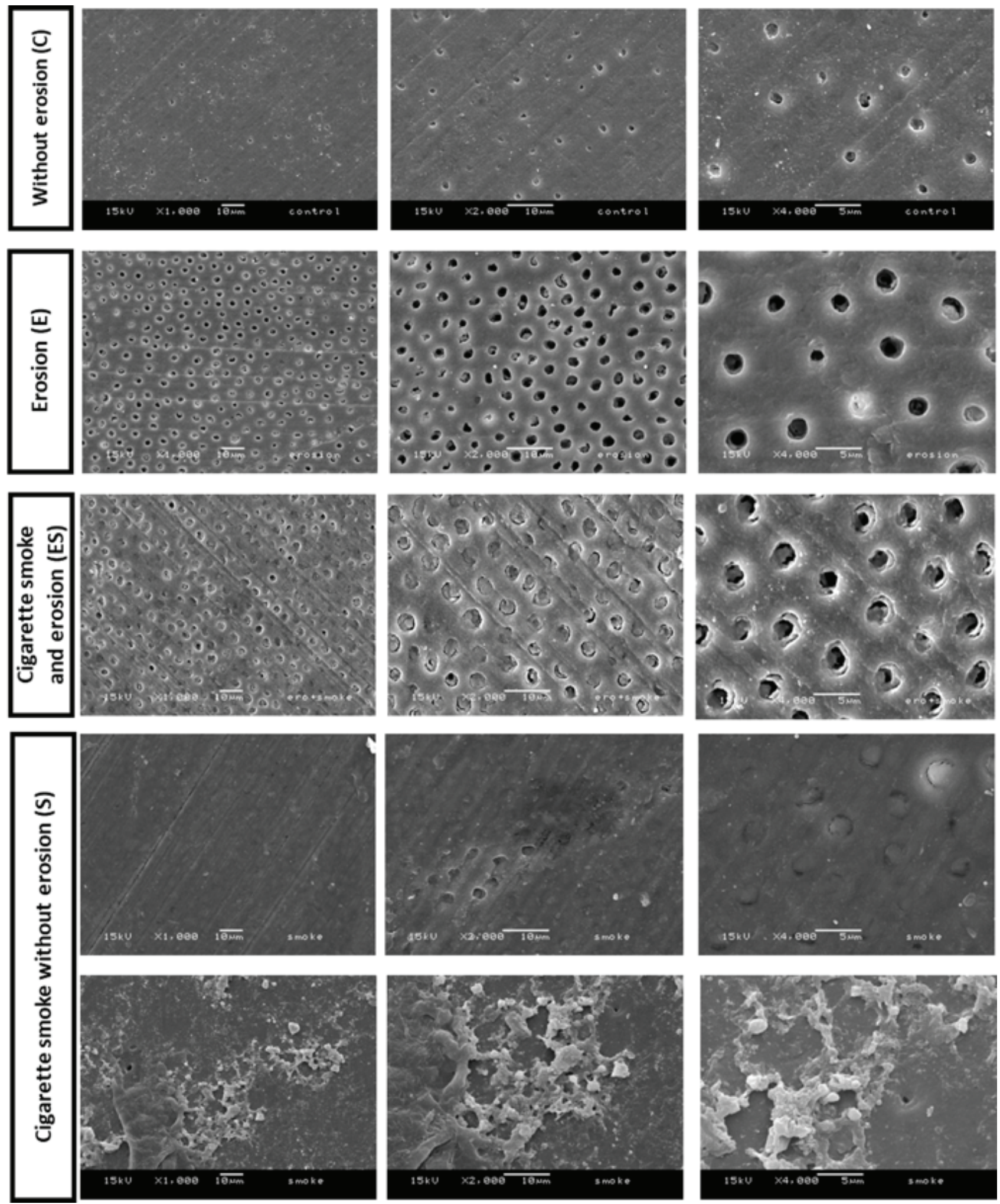

Figure 2 - Representative SEM images (X1000) of dentin surface after exposure to cigarette smoke associated or not with erosion. 


\section{DISCUSSION}

The results suggest that the cigarette smoke with erosion association did not interfere on bond strength of self-etching adhesive system to dentin. Therefore, the null hypothesis tested was accepted.

Dental erosion occurs due to the presence of hydrogen ions released from strong / weak acids agents, by anions that can be activated by complexing with calcium, being known as chelating agents [22]. However, a simple strong acid such as hydrochloric acid is less common in the oral environment. Thus, the major concern should occur with the weak acids, such as citric acid and acetic acid, as these are commonly found in beverages and foods [23]. Hydrogen ions are produced by acid dissociation in water, and the weaker the acid, the easier it is to dissociate and release $\mathrm{H}+$ ions. Citric acid can release three hydrogen ions per molecule, which can react with carbonates or phosphates present in hydroxyapatite crystals dissolving them and causing loss of dental structure [24]. The erosive challenge performed in this study occurred using an acid solution containing $0.3 \%$ citric acid in its composition at $\mathrm{pH}=3.25$, being considered a mild erosive protocol [20]. The contact of the solution with the dental surface caused a significant loss of hardness (Table 1) for the groups exposed to the erosive cycle ( $\mathrm{E}$ and $\mathrm{EF}$ ) when compared to the unexposed groups ( $\mathrm{C}$ and $\mathrm{F}$ ). Acids such as citric acid have a greater complex interaction with the dental structure because in aqueous media there is a formation of a mixture that contains hydrogen ions, acid anions (citrate) and molecules without dissociation. The quantities of the reaction products mentioned above, are calculated by the acid dissociation constant (pKa) and the $\mathrm{pH}$ of the solution. Hydrogen ions behaves exactly as described above and directly attacks the mineral surface composed by hydroxyapatite crystal. In addition, the citrate anion can form a calcium complex by removing it from the dental surface. Each acid has a different resistance to the complex formed with calcium, this resistance being dependent on the molecular structure of the complex and the ease with which it exhibits the same characteristics of calcium. Consequently, such substances as citric acid have dual demineralizing action [22].

When dentin was exposed to cigarette smoke and erosive cycle (FE), the smoke had no effect on the demineralizing process when compared to the group exposed only to erosive cycle (E) and did not differ statistically from each other.

Erosive process in dentin cause a loss of mineral structure presented in this substrate, such as collagen fibrils exposure and increase of the quantity and diameter of exposed dentin tubules (Figure 2B and 2C) [22,25]. In the present study no statistically difference in bond strength were observed between eroded groups and non-eroded groups. According Cruz et al., 2012 the changes in dentin structure did no interfere on bond strength of adhesive systems in dentin, once that eroded dentin presented similar bond strength values for conventional adhesive systems when compare with glass ionomer cement (GIC) and resin modified GIC. Authors suggest that adhesive materials are capable to promoting similar micromechanical retention in both substrates, despite a higher demineralization degree of eroded dentin [26].

In this study were applied a two-step selfetching adhesive system, which contains in its formulation functional monomers capable to chemically interacting with calcium presents in hydroxyapatite, the main dental compound [27]. The 10-MDP monomer is a bi-functional molecule, which can interact with others resin monomers, as well as with the dental structure. Its functional acid group (phosphate group) allows interaction with calcium ions, present in hydroxyapatite crystals $[28,29]$. This interaction results in an MDP-Ca salts formation with a high stability in aqueous medium, but also hydrolysis resistance, thus increase the restoration longevity $[27,30-32]$ 
Scientific evidence is limited as to regarding eroded dentin adhesion. It is uncertain how the chemical and microstructural changes presented in the dentin substrate due to erosive challenge can affect the long-term adhesive materials performance. Some studies suggest the bond strength quality impairment caused by an eroded dentin, regardless the adhesive system [25,3335]. However, the best option to restore eroded tooth structure, still being the adhesive systems combined with composite resin because these materials presented a greater acid-resistance in comparison with GIC and resin modified GIC [33].

According Wang and Spencer, 2004 and Sattabanasuk et al., 2005, the greater the demineralization degree in eroded dentin substrate, the greater the depth of demineralization. These increases of demineralization depth allow formation of a thick hybrid layer from monomeric penetration into the substrate, in comparison with a sound dentin. Demineralized areas whose were not covered by monomers are structurally imperfect and had porosities, which comprising predominantly hydrophilic areas. This can contribute to dentin bond strength decrease [36,37].

Some studies in the literature suggest a decrease of dentin bond strength to teeth exposed to cigarette smoke $[7,8]$. However, in this study was not observed the decrease of self-etching adhesive system bond strength decrease in an eroded dentin as exposed to cigarette dentin substrate. More studies are necessary to a better knowing about the action mechanism of this type of adhesive system on eroded dentin surfaces as exposed to cigarette smoke.

\section{CONCLUSION}

Cigarette smoke exposure did not promote any effect in the percentage of microhardness loss, as in sound dentin as in eroded dentin. Cigarette smoke, erosion, and association of both, did not alter the bond strength of self-etching adhesives to dentin.

\section{Acknowledgments}

The authors thank the Coordenação de Aperfeiçoamento de Pessoal de Nível SuperiorBrasil (CAPES- Finance code 001) for the support in this study, and also thank the Piracicaba Dental School (FOP-UNICAMP) for provide the laboratory area to this research development.

\section{Conflict of Interest}

The authors state that there were no financial and personal conflicts of interest that could have influenced this study.

\section{REFERENCES}

1. World Health Organization. Who report on the global tabacco epidemic 2015: raising taxes on tobacco. Geneva, Switzerland: WHO Press; 2015.

2. World Health Organization. WHO global report on trends in prevalence of tobacco smoking 2000-2025. 2nd ed. Geneva, Switzerland: WHO Press; 2018.

3. Vellappally S, Fiala Z, Smejkalová J, Jacob V, Somanathan R. Smoking related systemic and oral diseases. Acta Medica (Hradec Kralove) 2007; 50(3):161-6.

4. Pinzon LM, Oguri M, O'Keefe K, Dusevish V, Spencer P, Powers JM, et al. Bond strength of adhesives to dentin contaminated with smoker's saliva. Odontology. 2010;98(1):37-43. doi:101007/s10266-009-0109-4.

5. Takeuchi CY, Corrêa-Afonso AM, Pedrazzi H, Dinelli W, Palma-Dibb RG. Deposition of lead and cadmium released by cigarette smoke in dental structures and resin composite. Microsc Res Tech. 2011;74(3):287-91. doi:10.1002/jemt.20903.

6. TA, Cavalcanti AN, da Rocha Nogueira-Filho G. Morphologic texture characterization allied to cigarette smoke increase pigmentation in composite resin restorations. J Esthet Restor Dent. 2010;22(4):252-9. doi:10.1111/j.1708-8240.2010.00347.x

7. Theobaldo JD, Catelan A, Rodrigues-Filho U, Marchi GM, Lima D, Aguiar F. Effect of cigarette smoke on resin composite bond strength to enamel and dentin using different adhesive systems. Oper Dent. 2016;41(3):E57-E63. doi:10.2341/15-056-L.

8. Almeida e Silva JS, de Araujo EM Jr, Araujo E. Cigarette smoke affects bonding to dentin. Gen Dent. 2010;58(4):326-330.

9. Chu CH, Lam A, Lo EC. Dentin hypersensitivity and its management. Gen Dent. 2011;59(2):115-24.

10. Al-Dlaigan $Y H$, Shaw $L$, Smith A. Dental erosion in a group of British 14-year-old school children. Part II: Influence of dietary intake. Br Dent J. 2001;190(5):258-61. doi:10.1038/sj.bdj.4800943.

11. Clapp 0, Morgan MZ, Fairchild RM. The top five selling UK energy drinks: implications for dental and general health. Br Dent J. 2019;226(7):493-7. doi:10.1038/s41415-019-0114-0

12. Nguyen Ngoc C, Ghuman T, Ahmed SN, Donovan TE. The erosive potential of additive artificial flavoring in bottled water. Gen Dent. 2018;66(5):46-51.

13. Ten Cate JM, Imfeld T. Dental erosion, summary. Eur J Oral Sci. 1996;104(2( Pt 2)):241-4. doi:10.1111/j.1600-0722.1996.tb00073.x 
14. O'Toole S, Bartlett $\mathrm{D}$. The relationship between dentine hypersensitivity, dietary acid intake and erosive tooth wear. J Dent. 2017;67:84-7. doi:10.1016/j.jdent.2017.10.002

15. Ding M, Shin SW, Kim MS, Ryu JJ, Lee JY. The effect of a desensitizer and CO2 laser irradiation on bond performance between eroded dentin and resin composite. J Adv Prosthodont. 2014;6(3):165-70. doi:10.4047/ jap.2014.6.3.165

16. Bartlett DW, Evans DF, Smith BG. Oral regurgitation after reflux provoking meals: a possible cause of dental erosion? J Oral Rehabil. 1997;24(2):1028. doi:10.1046/j.1365-2842.1997.d01-267.x

17. Manuja N, Nagpal R, Pandit IK. Dental adhesion: mechanism, techniques and durability. J Clin Pediatr Dent. 2012;36(3):223-34

18. Xie J, Powers JM, McGuckin RS. In vitro bond strength of two adhesives to enamel and dentin under normal and contaminated conditions. Dent Mater. 1993;9(5):295-9. doi:101016/0109-5641(93)90046-s

19. Theobaldo JD, Vieira-Junior WF, Catelan A, Mainardi MDCA, Ysnaga OA Rodrigues-Filho UP, et al. Effect of heavy metals contamination from cigarette smoke on sound and caries-like enamel. Microsc Microanal. 2018;24(6):762-7. doi:10.1017/S1431927618015404.

20. Guedes AP, Moda MD, Suzuki TY, Godas AG, Sundfeld RH, Briso AL, et al. Effect of fluoride-releasing adhesive systems on the mechanical properties of eroded dentin. Braz Dent J. 2016;27(2):153-9. doi: 10.1590/0103-644020160635

21. Bertoldo CES, Miranda DA, Souza Junior EJ, Aguiar FHB, Lima DANL, Ferreira RL, et al. Surface hardness and color change of dental enamel exposed to cigarette smoke. Int J Dent Clin 2011:3(4):1-4

22. Shellis RP, Featherstone JD, Lussi A. Understanding the chemistry of dental erosion. Monogr Oral Sci. 2014;25:163-79. doi: 10.1159/000359943. Epub 2014 Jun 26. Review. PubMed PMID: 24993265

23. Lussi A, Jaeggi T, Zero D. The role of diet in the aetiology of dental erosion. Caries Res. 2004;38 Suppl 1:34-44. doi:10.1159/000074360

24. Featherstone JD. The science and practice of caries prevention. J Am Dent Assoc. 2000;131(7):887-99. doi:10.14219/jada.archive.2000.0307.

25. Zimmerli B, De Munck J, Lussi A, Lambrechts P, Van Meerbeek B. Longterm bonding to eroded dentin requires superficial bur preparation. Clin Oral Investig. 2012;16(5):1451-61. doi:10.1007/s00784-011-0650-8.
26. Cruz JB, Lenzi TL, Tedesco TK, Guglielmi Cde A, Raggio DP. Eroded dentin does not jeopardize the bond strength of adhesive restorative materials. Braz Oral Res. 2012;26(4):306-12. doi:101590/s180683242012005000009

27. Giannini M, Makishi P, Ayres AP, Vermelho PM, Fronza BM, Nikaido T, et al Self-etch adhesive systems: a literature review. Braz Dent J. 2015;26(1):310. doi: 10.1590/0103-6440201302442

28. Yoshida Y, Van Meerbeek B, Nakayama Y, et al. Adhesion to and decalcification of hydroxyapatite by carboxylic acids. J Dent Res. 2001;80(6):1565-9. doi:10.1177/00220345010800061701

29. Fukegawa D, Hayakawa S, Yoshida Y, Suzuki K, Osaka A, Van Meerbeek B. Chemical interaction of phosphoric acid ester with hydroxyapatite. J Dent Res. 2006;85(10):941-4. doi: 10.1177/154405910608501014.

30. Matsui N, Takagaki T, Sadr A, et al. The role of MDP in a bonding resin of a two-step self-etching adhesive system. Dent Mater J. 2015;34(2):227-33. doi:10.4012/dmj.2014-205.

31. Yoshida Y, Nagakane K, Fakuda R, Nakayama Y, Okazaki M, Shintani H et al Comparative study on adhesive performance of functional monomers. $J$ Dent Res. 2004;83(6):454-8. doi:10.1177/154405910408300604.

32. Turp V, Sen D, Tuncelli B, Ozcan M. Adhesion of 10-MDP containing resin cements to dentin with and without the etch-and-rinse technique. J Adv Prosthodont. 2013:5(3):226-33. doi:10.4047/jap.2013.5.3.226.

33. Cruz JB, Bonini G, Lenzi TL, Imparato JC, Raggio DP. Bonding stability of adhesive systems to eroded dentin. Braz Oral Res. 2015;29:S180683242015000100284. doi:10.1590/1807-3107BOR-2015.vol29.0088.

34. Flury S, Koch T, Peutzfeldt A, Lussi A, Ganss C. The effect of a tincontaining fluoride mouth rinse on the bond between resin composite and erosively demineralised dentin. Clin Oral Investig. 2013;17(1):217-25. doi:10.1007/s00784-012-0697-1

35. Flury S, Lussi A, Peutzfeldt A. Long-Term bond strength of two benzalkonium chloride-modified adhesive systems to eroded dentin. Biomed Res Int. 2017;2017:1207208. doi:101155/2017/1207208.

36. Wang Y, Spencer P.Effect of acid etching time and technique on interfacial characteristics of the adhesive-dentin bond using differential staining. Eur J Oral Sci. 2004;112(3):293-9. doi:10.1111/j.1600-0722.2004.00127.x.

37. Sattabanasuk V, Shimada $Y$, Tagami J. Bonding of resin to artificially carious dentin. J Adhes Dent Autumn. 2005; 7(3):183-92

\section{Marcela Alvarez Ferretti}

(Corresponding address)

Av. Limeira, 901, Zip code 13.414-903, Piracicaba, SP, Brazil.

Date submitted: 2020 Jan 05

E-mail: marcela.a.ferretti@gmail.com 